\title{
The effects of the soil tillage and the fertilization on the relative chlorophyll content (SPAD-values) of the maize (Zea Mays L.) leaves
}

\author{
László DUZS - Péter RAGÁN - Péter FEJÉR - András VÁNTUS - Tamás RÁTONYI \\ Institute of Land Utilisation Technology and Regional Development, Faculty of Agricultural and Food Sciences \\ and Environmental Management, University of Debrecen, H-4032 Debrecen, Böszörményi street. 138, \\ E-mail: laszloduzs5@gmail.com
}

Keywords: maize, SPAD value, long-term field experiment,

\section{Introduction}

From the economical point of view it is important to define the suitable cultivation manner and the optimal nutrient supply, because their proper selection is a key factor to reach optimal maize yields. It has an influence to the allometric growth of the maize and the grain-stem proportion (Wasaya 2017; Shi 2016). Yang(2017) found that the cultivation system has an impact on the chlorophyll content of the leaves and on the intensity of photosynthesis. SPAD values are suitable to determinate the chlorophyll content of the plant (Sowiński, 2018), which are in correlation with the plant health and the amount of yield.

\section{Materials and methods}

The polyfactorial long-term maize field experiment is situated at the trial site of the University of Debrecen (Hajdúság loess plateau, 47 30' N, 21 $1^{\circ} 36^{\prime} \mathrm{E}, 121 \mathrm{~m}$ elevation) in 2018. The soil type of the experimental site is a lowland calcareous chernozem, which is one of the major soil types of the region. The experiment was arranged in split-split-plot, on the main plots there were three tillage and two irrigation varieties. Maize hybrids were planted onto the primary sub-plots with a plant number of 60-80 thousand ha-1, while nonfertilized and fertilization treatments take place randomized on the secondary sub-plots. The investigated tillage treatments were moldboard ploughing (MP) to a depth of $0.3 \mathrm{~m}$, strip tillage (ST) to a depth of $0.3 \mathrm{~m}$ and ripping (RP) to a depth of $0.45 \mathrm{~m}$.

Our measurements were carried with Minolta SPAD-502 at 3 phenological phase (4 leaf stage, 10 leaf stage and silking. The measurements were performed in 10 repetitions on the top leaf in the case of 4-leaf and 10-leaf stages, while on the leaf located opposite the ear in the case of silking. The tool calculates chlorophyll content, namely SPAD, ranging from 1 to 100 (Minolta Camera Co. Ltd., 1990). To analyse the relations between the tillage system, the fertilization and the SPAD-values we used the repeated measurement model by Huzsvai és Balogh (2015)

\section{Results and discussion}

Both of the amount of fertilizers and the tillage system have an effect on the measured SPAD values.(Figure 1) In the case of the control plots we realized that the highest SPAD values were found in the strip tillaged plots. No significant correlation was found between the values from the ploughed and the subsoiled parcels. In relation with the data measured for the second fertilizer treatment, statistically verifiable difference was found amongst the measured values. We measured the highest values on the subsoiled (ripped) parcels. The highest values were found with the $160 \mathrm{~kg} \mathrm{~N} /$ ha dose strip tillaged parcels. 
The increased amount of applied nitrogen on the ploughed plots had an effect on the measured SPAD values. This trend cannot be realized on the strip tillaged plots, because in the case of the second fertilization treatment, there was a decline in terms of the SPAD values. There was a statistically verifiable difference in the case of the strip tillaged plots, amongst the areas treated with three different nitrogen amounts. There was a significant difference between the SPAD values of the control plot and the measured data of the plots treated with increased amount of nitrogen.

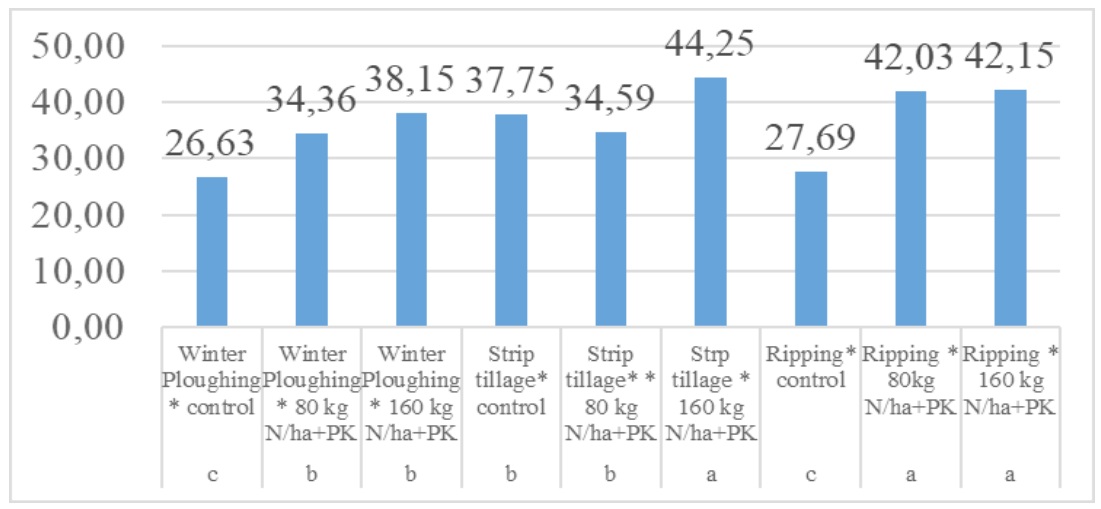

Figure 1: The effect of nitrogen dose and tillage on SPAD values at the 60 thousand plant/ha density

\section{Conclusions}

Both nutrient supply both the tillage method influenced the measured SPAD values. In the case of ploughing, increased applied nitrogen doses resulted in higher SPAD values.

\section{Acknowledgement}

The research was financed by the Higher Education Institutional Excellence Programme of the Ministry of Human Capacities in Hungary, within the framework of the 4.thematic programme of the University of Debrecen, and the projects "GINOP-2.2.1-15-2016-00001

- Developing a scale-independent complex precision consultancy system" and "EFOP3.6.3-VEKOP-16-2017-00008".

\section{References}

Wasaya A., Muhammad, T., Hakoomat A. Mubshar H.-Tauqeer A.Y.-Ahmad S.-Muhammad I,aAbdulsattar (2017): Influence of varying tillage systems and nitrogen application on crop allometry, chlorophyll contents, biomass production and net returns of maize (Zea mays L.) https://doi.org/10.1016/j.still.2017.02.006

Jinli D.-Yunhong Z., Jicheng W., Jiemei. Z. Xiaoying P., Cuimin G.,Yue W., Fang H. (2017): Effects of tillage and mulching measures on soil moisture and temperature, photosynthetic characteristics and yield of winter wheat

Sowiński J., Głąb L.(2018): The effect of nitrogen fertilization management on yield and nitrate contents in sorghum biomass and bagasse https://doi.org/10.1016/j.fcr.2018.08.006

Yu Z., Yu. J.M., Shangyu.M., Zhiqiang G., Yongli Z. (2016): Tillage practices affect dry matter accumulation and grain yield in winter wheat in the North China Plain https://doi.org/10.1016/j.still.2016.02.009

Minolta (1990): Specifications in detail - chlorophyll meter SPAD 502. Minolta Technical Note. TE102-601-01.

Huzsvai L., Balogh P. (2015): Lineáris modellek az R-ben. Seneca Books, Debrecen. 109-124. 